DR. NICOLAS KLUGER (Orcid ID : 0000-0002-5225-8316)

Article type : Letter to Editor

\title{
Tattoos among elite football players during the 2019 FIFA Women's World Cup France
}

\author{
Nicolas Kluger ${ }^{1,2}$ \\ ${ }^{1}$ Departments of Dermatology, Allergology and Venereology, Helsinki University Central \\ Hospital, Meilahdentie 2, P.O. Box 160, 00029 HUS, Finland \\ ${ }^{2}$ "Tattoo» Consultation, Department of Dermatology, Bichat-Claude Bernard Hospital, \\ Assistance Publique-Hôpitaux de Paris, 46 rue Henri Huchard, 75877, Paris Cedex 18, France. \\ orcid.org/0000-0002-5225-8316
}

Corresponding address

Department of dermatology, Skin and Allergies Hospital, Helsinki University Central Hospital, Meilahdentie 2, P.O. Box 160, 00029 HUS, Finland

Phone + 358 (0) 947186475

Fax $+358(0) 947186561$

nicolas.kluger@hus.fi

Twitter account: @NicoKluger

Key words: football; penalty; performance; soccer; sport; tattoo

Conflict of interest: none declared

Funding sources: none

This article has been accepted for publication and undergone full peer review but has not been through the copyediting, typesetting, pagination and proofreading process, which may lead to differences between this version and the Version of Record. Please cite this article as doi: $10.1111 /$ jdv. 15890

This article is protected by copyright. All rights reserved. 
Editor

Thirty-four percent of the men players harbored visible tattoos, without notable impact on performance or discipline on the field during the 2018 FIFA World Cup (FWC), [1]. In a spirit of gender equality, we performed the same study among elite women footballers enrolled in the 2019 FWC France with the same methodology [1]. Players' visible tattoos (location, colours) were reviewed using the Getty Images website [2]. We collected players and teams' statistics using the official FIFA website [3].

Among the 552 enrolled players (median age 26 years), 164 (29.8\%) had visible tattoos (upper limbs, 99\%; head and neck, 11\%; lower limbs, 7.3\%; black/grey tattoos, 85\%). There were no significant differences regarding age or player's position (Table 1). Players from Latin America had the highest prevalence of visible tattoos (56.5\%). African players displayed significantly more head and neck tattoos than Europeans ( $28.6 \%$ vs $6.3 \%, p=0.034$ ) (Table 2 ). The prevalence ranged from $60.9 \%$ (Brazil) to 0\% (Japan).

The number of scorers, the mean number of goals scored, and the proportion of players with yellow/red cards were similar between tattooed and non-tattooed players (Table 1). There was no correlation between having tattoos and number of goals scored (Spearman rho 0.029, $p=0.562$ ). We found no differences between tattoos, players' positions and yellow/red cards (data not shown).

Out of the 24 enlisted teams, 16 qualified for the knockout stage: $66 \%$ of the tattooed players qualified (108/164). The mean number of tattooed players in teams that qualified for the knockout stage and in those which did not was similar $(7.0 \pm 3.9$ vs $6.7 \pm 3.9, p>0.05)$. There was no difference between the final four teams (USA, the Netherlands, Sweden and England) and the other teams (7.7 \pm 1.5 vs $6.7 \pm 4.1, p>0.05)$. We failed to find any correlation on a team level between the prevalence of tattooed players and performance (total scored goals, total goals against, shots, attempts on target, goal/attempts ratio) or discipline (total yellow and red cards, fouls committed or fouls/game ratio).

This article is protected by copyright. All rights reserved. 
Twenty-three penalties were scored (out of $33,69.7 \%$ ) during the FWC. The success and saving rate was similar between non-tattooed and tattooed shooters/goalkeepers (table 1).

Almost $30 \%$ of the women football players had visible tattoos during the 2019 FWC France. This proportion is similar to the prevalence in the general population for the same age range (25-34 y, 27.3\%) [4]. We found similarities between women and men footballers in 2018 regarding the overall prevalence $(34 \%)$, black tattoos ( $85 \%$ vs $83 \%$ ), the proportion of tattooed scorers ( $34.9 \%$ vs $40 \%$ ) and of goals scored by tattooed players (36\% vs $37 \%$ ) [1]. We found no association with discipline, team and personal performance, including penalties success or fail [5].

Visible tattoos are also popular in national women football teams. We collected visible tattoos but players may have additional tattoos on the upper body (chest, back, shoulders, groins or feet). We may have missed small visible tattoos. Besides, some footballers play with upper long sleeves $(n=28)$, goalkeepers especially $(n=24)$. Therefore, the prevalence of tattoos is most likely higher. Besides, the number of games by team is low (from 3 to 7 ) and 110 players (19.9\% of all the players) did not have any playing time, which may have an impact on performance and discipline. Lastly, we did not analyze size, number or design of the tattoos. We had the impression that women favored smaller and discrete tattoos, compared to male players who displayed more often extensive tattooed sleeves. As for men $[1,5]$, having tattoos did not seem to provide any individual advantage or disadvantage on the field for women footballers at that level of competition.

This article is protected by copyright. All rights reserved. 


\section{References}

1. Kluger N, Samimi M. Tattoos among elite football players during the 2018 FIFA World Cup Russia. J Eur Acad Dermatol Venereol. 2019;33:e132-e134.

2. https://www.gettyimages.fi/creative-images [accessed 09 July 2019]

3. https://www.fifa.com/womensworldcup/teams/ [accessed 09 July 2019]

4. Kluger $\mathrm{N}$, Seité $\mathrm{S}$, Taieb $\mathrm{C}$. The prevalence of tattooing and motivations in five major countries over the world, J Eur Acad Dermatol Venereol 2019, under press.

5. Müller SM, Hogg S, Itin P. Tattoos and Penalty Success at the FIFA World Cup 2018. Dermatology. 2018;234:226-228

This article is protected by copyright. All rights reserved. 


\section{Tables}

Table 1. Characteristics of tattooed versus non-tattooed footballers during the 2019 FIFA World Cup France $\left(n=551^{*}\right)$

\begin{tabular}{|c|c|c|c|}
\hline & $\begin{array}{l}\text { Players with tattoos } \\
n=164\end{array}$ & $\begin{array}{l}\text { Players without } \\
\text { tattoos } \\
n=387\end{array}$ & $\begin{array}{l}\text { Fisher's exact test or } \\
\text { Student t-test } \\
\text { p-value }\end{array}$ \\
\hline Mean age (SD) & $26.4(4.0)$ & $25.9(4.1)$ & NS \\
\hline \multicolumn{4}{|c|}{ Geographical distribution, $n$ (\%) } \\
\hline Europe $(n=207)$ & $62(29.9)$ & 145 & Reference \\
\hline Americas ( $n=138$ ) & $59(42.7)$ & 79 & 0.016 \\
\hline North America $(n=69)$ & $20(30.0)$ & 49 & NS \\
\hline South America $(n=69)$ & $39(56.5)$ & 30 & 0.0001 \\
\hline Asia $(n=92)$ & $12(14.1)$ & 80 & 0.0014 \\
\hline Africa $(n=69)$ & $14(20.3)$ & 55 & NS \\
\hline Oceania $(n=45)$ & $17(37.8)$ & 28 & NS \\
\hline \multicolumn{4}{|l|}{ Field position, $n(\%)$} \\
\hline Forward $(n=139)$ & $44(31.6)$ & 95 & Reference \\
\hline Midfielder $(n=163)$ & $54(33.1)$ & 109 & NS \\
\hline Defender $(n=178)$ & $51(28.8)$ & 126 & NS \\
\hline Goalkeeper $(n=72)^{* *}$ & $15(20.8)$ & 57 & NS \\
\hline \multicolumn{4}{|c|}{ Goals, $n(\%)$, total $n=413^{* * *}$} \\
\hline & $\begin{array}{l}\text { Players with tattoos } \\
n=133\end{array}$ & $\begin{array}{l}\text { Players without } \\
\text { tattoos } \\
n=280\end{array}$ & \\
\hline $\begin{array}{l}\text { Total scored }(n=138) \\
\text { Number of scorers } \\
(n=83) \\
\text { Ratio by field players } \\
\text { Mean number (SD) }\end{array}$ & $\begin{array}{l}50(36.2) \\
29(21.8) \\
0.21 \\
0.38(0.94)\end{array}$ & $\begin{array}{l}88(63.8) \\
54(19.3) \\
0.19 \\
0.31(0.81)\end{array}$ & $\begin{array}{l}\text { NS } \\
- \\
\text { NS }\end{array}$ \\
\hline
\end{tabular}

This article is protected by copyright. All rights reserved. 


\begin{tabular}{|c|c|c|c|}
\hline \multicolumn{4}{|c|}{ Penalties, $n(\%)$, total $\mathrm{n}=33^{* * * *}$} \\
\hline $\begin{array}{l}\text { Penalties taken } \\
\text { Penalties scored } \\
\text { Penalties prevented by } \\
\text { goalkeepers***** }\end{array}$ & $\begin{array}{l}16 \\
11(68.7) \\
3(27.3)\end{array}$ & $\begin{array}{l}17 \\
12(70.6) \\
7(31.8)\end{array}$ & NS \\
\hline \multicolumn{4}{|c|}{ Disciplinary, $n(\%)$, total $n=442 * * * * * *$} \\
\hline & $\begin{array}{l}\text { Players with tattoos } \\
n=141\end{array}$ & $\begin{array}{l}\text { Players without } \\
\text { tattoos } \\
n=301\end{array}$ & \\
\hline $\begin{array}{l}\text { Players with any cards } \\
\text { Players with yellow } \\
\text { cards } \\
\text { Players with red cards } \\
\text { Number of yellow cards } \\
\text { ( } n=124) \\
\text { Mean number of yellow } \\
\text { cards (SD) } \\
\text { Numbers of red cards } \\
\text { ( } n=4) \\
\text { Mean number of red } \\
\text { cards (SD) }\end{array}$ & $\begin{array}{l}34(24.1) \\
33(23.4) \\
1(0.7) \\
41(33.0)\end{array}$ & $\begin{array}{l}0.28(0.49) \\
3(75) \\
0.01(0.10)\end{array}$ & NS \\
\hline
\end{tabular}

NS: Not significant; SD: Standard Deviation

*1 player from New Zealand had no picture available.

** Upper long sleeves

*** Goalkeepers excluded $(n=29)$ and players who did not played any game excluded $(n=110)$ ****Five goalkeepers played with upper long sleeves ("non-tattooed"). Even if we excluded them, the difference remains not significant $(p>0.05)$.

$* * * * *$ includes saves by the goalkeepers and missed shots by the shooter ******Players who did not played any game excluded $(n=110)$

This article is protected by copyright. All rights reserved. 
Table 2. Tattoos by location on body parts and geographic area among women footballers during the 2019 FIFA World Cup France

\begin{tabular}{|c|c|c|c|c|}
\hline $\begin{array}{l}\text { Continent (total } \\
\text { players) }\end{array}$ & $\begin{array}{l}\text { Arm } \\
n(\%)\end{array}$ & $\begin{array}{l}\text { Lower limb } \\
n(\%)\end{array}$ & $\begin{array}{l}\text { Head and neck } \\
n(\%)\end{array}$ & $\begin{array}{l}\text { Fisher's exact test } \\
\text { p-value }\end{array}$ \\
\hline Europe $(n=62)$ & $62(100)$ & $4(6.3)$ & $4(6.3)$ & Reference \\
\hline Americas $(n=59)$ & $58(98.3)$ & $4(6.8)$ & $10(16.5)$ & NS \\
\hline $\begin{array}{l}\text { North America } \\
(n=20)\end{array}$ & $20(100)$ & $1(5)$ & $3(15)$ & NS \\
\hline $\begin{array}{l}\text { South America ( } n \\
=39 \text { ) }\end{array}$ & $38(97.4)$ & $3(7.7)$ & $7(17.9)$ & NS \\
\hline Africa $(n=14)$ & $13(100)^{*}$ & $3(21.4)$ & $4(28.6)$ & $0.034^{* *}$ \\
\hline Asia $(n=12)$ & $12(100)$ & - & $1(8.3)$ & NS \\
\hline Oceania $(n=17)$ & $17(100)$ & $1(5.9)$ & - & NS \\
\hline Total $(n=164)$ & 162 (99)* & $12(7.3)$ & $19(11.6)$ & NS \\
\hline
\end{tabular}

NS: Not significant

*A south African player with head and neck tattoo played with long sleeves

${ }^{* *} p=0.034$ for head and necks tattoos. NS for lower limbs tattoos.

This article is protected by copyright. All rights reserved. 